\title{
The Influence of Leadership, Competence and Job Satisfaction on the Performance of Nagari Employees in Sintoga Sub-District

\author{
Suharyono, Erni Masdupi, Rahmiati
}

\begin{abstract}
This study aims to analyze the influence of leadership, competence, and job satisfaction on the performance of Nagari employees in the Sintoga sub-district. The population of this study was Nagari employees in Sintoga sub-district. The population of this study was Nagari employees in Sintoga sub-district, with a total sample of 147 respondents. The analysis technique used in this research is the Multiple Linear Regression analysis.
\end{abstract}

Keywords: leadership, competence, job satisfaction, performance

\section{INTRODUCTION}

$E_{\text {ffective employee performance must be able to carry }}$ out the vision and mission of the organization by established standards or continue the existing vision and mission. The vision and mission of the Nagari in Sintoga sub-district is to make the Nagari implement sharia in Padang Pariaman.

In Nagari governance, the performance of the Nagari apparatus is supported by the Nagari Government Budget (APBN) provided by the District Government which can be used based on a predetermined usage system. So the performance of the village apparatus in the Nagarian must be evaluated and improved continuously. The process of assessing the performance of the village apparatus cannot be separated from the responsibility of the leaders, the competence of the Nagari Apparatus, and the job satisfaction of the village apparatus in the agency.

Based on the phenomena in the field, it was found that several Nagari apparatus were less skilled in their fields in writing letters and administrative systems. Also, not all Nagari devices that work in the village have had expertise in operating computers and the technology provided to support the work carried out. Likewise, the time needed to obtain the desired information and letters does not have a clear information system with a relatively efficient time according to what is needed by the community. The performance of the Nagari employees is influenced by the leadership of the wali Nagari. [1] shows that leadership affects employee performance. Furthermore, [2] research result shows that there is an effect of leader effectiveness on employee

Revised Manuscript Received on January 15, 2021.

* Correspondence Author

Suharyono*, Student of Master of Management at Universitas Negeri Padang, Indonesia. Email: suharyonomanajemen@gmail.com

Erni Masdupi, Lecturer of Master of Management at Universitas Negeri Padang, Indonesia. Email: gombangsuri@gmail.com

Rahmiati, Lecturer of Master of Management at Universitas Negeri Padang, Indonesia. Email: rahmifeunp@gmail.com

(C) The Authors. Published by Blue Eyes Intelligence Engineering and Sciences Publication (BEIESP). This is an open access article under the CC BY-NC-ND license (http://creativecommons.org/licenses/by-nc-nd/4.0/) performance. A good leader must also be able to adjust and develop himself and be able to master and direct and develop influence on his employees. In an organization, leadership is the central point and determination of policies for activities to be carried out the organization. Leadership is the art of managing or the process of influencing others.

Another factor that affects performance is competence, according to the results of research by Mc Clelland [3], showing that non-academic competencies, such as the ability to generate innovative ideas, management skills speed of learning networks, and so on managed to predict individual achievement in his work. The results of research by [4] and [5] show that competence affects employee performance.

Another factor that affects performance, namely job satisfaction is one of the important factors that need to be considered by leaders in an organization to achieve organizational goals. Besides, job satisfaction is also one of the basic needs of a job. Job satisfaction is one of the important aspects than an employee must have to be able to work properly as expected. Job satisfaction can be defined as one of the conditions in a person who feels satisfied, relieved and happy because situations and conditions can fulfil his wants, needs, hopes and ambitions. The term job satisfaction is interpreted differently by experts. This is due to differences in the meaning and purpose of satisfaction itself for each individual. [6] job satisfaction shows a person's positive or negative attitude about their work. The concept of job satisfaction is referred to as "The overall affective orientation on the part of individuals regarding their current job roles".

\section{METHODS}

This type of research used in this research is descriptive causative research. This study aims to explain the influence of leadership, competence, and job satisfaction on the performance of Nagari employees in Sintoga sub-district, Padang Pariaman Regency. The population of this study were Nagari employees in Sintoga sub-district, Padang Pariaman Regency with a sample of 147 respondents. The sampling method used for this study was Proportional to Random Sampling.

\section{RESULTS}

A. The Influence of Leadership on the Performance of Nagari Employees in Sintoga sub-district

Based on the results of testing the first hypothesis, the variable leadership (X1) obtained tcoun of 14.170 with a probability of 0.000 , which value is below 0.05 . Thus $\mathrm{H} 1$ is accepted, which means that there is a partially significant positive influence of leadership (X1) on employee performance $(\mathrm{Y})$.

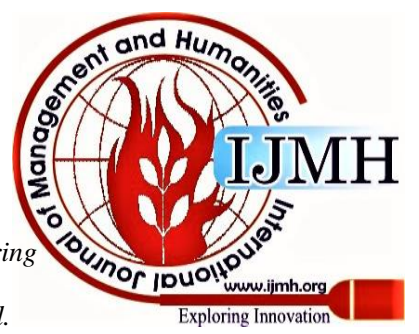


The Influence of Leadership, Competence and Job Satisfaction on the Performance of Nagari Employees in Sintoga Sub-District

It can be concluded that leadership can improve the performance of Nagari employees in Sintoga sub-district.

B. The Effect of Competence on the Performance of Nagari Employees in Sintoga sub-district

Based on the results of testing the second hypothesis, it is found that competence (X2) is obtained by t count of 3,280 with a probability of 0.001 , which is below 0.05 . Thus $\mathrm{H} 2$ is accepted, which means that there is a partial influence between the competency variable (X2) on employee performance (Y). So it can be concluded that competence can improve the performance of Nagari employees in Sintoga sub-district.

\section{The Effect of Job Satisfaction on the Performance of Nagari Employees in Sintoga sub-district}

Based on the results of testing the third hypothesis, it is found that job satisfaction (X3) obtained tcount of 2.757 with a probability of 0.007 , which is below 0.05 . Thus $\mathrm{H3}$ is accepted, which means that there is an influence between job satisfaction variable (X3) Partially on employee performance (Y). So it can be concluded that job satisfaction can improve the performance of Nagari employees in Sintoga sub-district.

Table- I: Recapitulation of the results of multiple linear regression analysis

\begin{tabular}{|c|c|c|c|c|c|c|}
\hline & \multirow[t]{2}{*}{ Model } & \multicolumn{2}{|c|}{$\begin{array}{l}\text { Unstandardized } \\
\text { Coefficients }\end{array}$} & \multirow{2}{*}{$\begin{array}{c}\text { Standardized } \\
\text { Coefficients }\end{array}$} & \multirow[t]{2}{*}{$\mathrm{t}$} & \multirow[t]{2}{*}{ Sig. } \\
\hline & & $\mathrm{B}$ & Std.Error & & & \\
\hline \multirow[t]{4}{*}{1} & (Constant) & 39.873 & 1.520 & - & 26.232 & .000 \\
\hline & Leadership & .322 & .023 & .682 & 14.170 & .000 \\
\hline & Competence & .104 & .032 & .177 & 3.280 & .001 \\
\hline & Job Satisfaction & .060 & 0.22 & .162 & 2,757 & .007 \\
\hline \multicolumn{2}{|c|}{$F=146.776 \quad R=0,8$} & $\mathrm{R}^{2}=0$ & & Sig $=0,000$ & & \\
\hline
\end{tabular}

\section{Discussion}

Based on the results of the analysis, it shows that there is a positive and significant influence of leadership on the performance of Nagari employees in Sintoga sub-district. If the value of the leadership variable increases, it will increase the value of the performance variable. The results of this study are supported by according to Anthony and [7], the most important factor affecting goal alignment is competence, while the factor that has the strongest impact on performance achievement is leadership. An organization in carrying out its activities must have a reliable leader, who can anticipate the future, and take opportunities from existing changes and be able to direct the organization to achieve its stated goals. Based on the results of research by [1], it shows that leadership affects employee performance. Furthermore, [2] research results show that there is an effect of leader effectiveness on employee performance. Based on the results of the analysis, competency has a positive and significant effect on the performance of Nagari employees in Sintoga sub-district. The results of this study are supported by research conducted by [4] dan [5] which shows that competence affects employee performance.

The high competence of Nagari employees will result in high performance. Competence in the form of skills, skills and behaviour makes employees understand their duties. But if employees have low competence, it will be difficult for them to carry out their duties so that it will result in low performance. Based on the results of the analysis, it shows that job satisfaction has a positive and significant effect on the performance of Nagari employees in Sintoga sub-district. The results of this study are supported by research conducted by [8] which shows that job satisfaction has a positive and significant effect on employee performance. Employees who are satisfied with their work will work better so that their performance increases. According to [3] states that attitudes or attitudes are evaluative statements about objects, people, or events. This attitude can be in the form of pleasant or unpleasant evaluative statements. Furthermore, [3] job satisfaction is a positive feeling about one's job which is the result of evaluating its characteristics. Job satisfaction reflects a person's feeling about his job and this can be seen in the behaviour and attitudes of employees in every life, usually shown in terms of positive or negative responses at work. Positive feedback at work will result in better performance.

\section{CONCLUSION}

Based on the results of research conducted on Nagari Employees in Sintoga sub-district, conclusions can be drawn 1) leadership has a positive and significant effect on the performance of Nagari employees in Sintoga sub-district; 2) Competence has a positive and significant effect on the performance of Nagari employees in Sintoga sub-district; and 3) job satisfaction has a positive and significant effect on the performance of Nagari employees in Sintoga sub-district.

\section{REFERENCES}

1. Wang, F. J., Jen, S. C, and Ling, T. M. "Effect of leadership style on organizational performance as viewed from human resource management strategy". African Journal of Business Management, 2010, 4(18).

2. Popa, B. M. "The Relationship Between Leadership Effectiveness and Organizational Performance". Journal of Defense Resource Management, 2012, 3(1).

3. Robbin, S., and Judge. T. "Organization Behavior". 15th ed. New Jersey: Person Education, 2009.

4. Rantesalu, A, and Mus, A. R. "The effect of competence, motivation and organizational culture on employee performance: The mediating role of organizational commitment". Journal of Reseacrh in Business and Management, 2016, 4(9), pp.8-14.

5. Jusmin, A., Said, S., Bima, M. J., and Alam, R. (2016). "Specific determinants of work motivation, competence, organizational climate, job satisfaction and individual performance: A study among lecturers". Journal of Business and Management Sciences, 2016, 4(3), pp. 53-59. 
6. Valaei, N., and Rezaei, S. (2016). "Job satisfaction and organizational commitment An empirical investigation among ICT-SMEs". Management Research Review, 2016, 39(12), pp. 1663-1694.

7. Anthony, R. N. and V. Govindarajan. 2005. "Management Control System”. 11 ed. Jakarta: Salemba Empat. 2005.

8. Jalagat, R. Jr. "Job Performance, Job Satisfaction and Motivation: A Critical Review of Their Job Performance, Job Satisfaction, and Motivation: A Critical Review of Their Relationship". International Journal of Advances in Management and Economics, 2016, 5(6), pp.36-42.

\section{AUTHORS PROFILE}

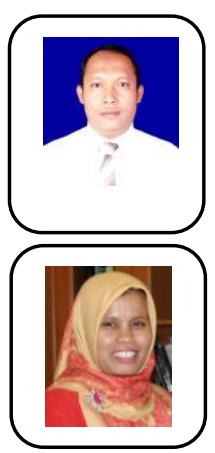

Suharyono, is a right now he is a Student of Master of Management at Universitas Negeri Padang, Indonesia

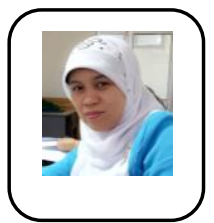

Erni Masdupi, is a right now he is a Student of Lecturer of Management at Universitas Negeri Padang, Indonesia.

Erni Masdupi, is a right now he is a Student of Lecturer of Management at Universitas Negeri Padang, Indonesia.

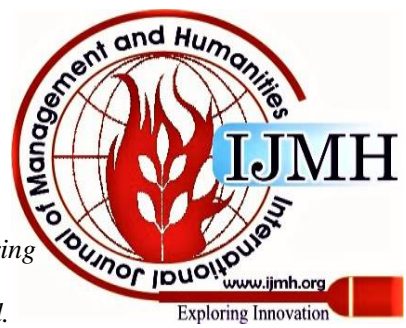

